\title{
Business model target map based on grounded theory methodology
}

\author{
Yafu Xu*, Xiaozhang Zhao, Weihong Wang \\ Glorious Sun School of Business and Management, Donghua University, Shanghai 201620, China
}

Corresponding Author Email: yafuxu@sina.com

DOI: $10.18280 /$ eesrj.050104

Received: 6 November 2017

Accepted: 25 March 2018

\section{Keywords:}

business model, business model target map, grounded theory methodology

\begin{abstract}
This paper attempts to make an accurate definition of business model and clearly identify its elements. To this end, the classical grounded theory was adopted and six experts on business model were invited to receive in-depth interviews. In this way, the author worked out the definition of business model and find out its key elements. Moreover, a new business model target map (BMTM) was plotted to depict the elements and the relationship among these elements. Besides, the BMTM also verifies the relationship between the model and strategy and target market. The research findings provide a clear guideline for business model design.
\end{abstract}

\section{INTRODUCTION}

Despite the extensive studies on the issue, there is no commonly accepted definition of business model. The concept of business model varies from scholar to scholar. Lack of widely accepted uniform definition and theory is becoming the bottle neck for further continuous and scientific study on business model [1]. In many cases, business model is treated as a common idiom in the academic and business circles [2]. Morris et al. divided business model into three dimensions: economy, operation and strategy, and defines the concept as follows: business model describes the strategic connotation, operational structure and economic logic, and creates a competitive edge through the integration of the related variables [3].

Most of the early definitions on business model were made from economic and operational perspectives. For example, Timmers suggested that business model is a system of product flow, service flow and information flow, which reflects the roles of various participants, potential benefits and income sources [4]. Linder held that business model is a logic description of a commercial organization or system [1]. Osterwalder believed that business model describes how a company makes profits, and buys/sells its products or services [5]. Amit regarded business model as a structural configuration system designed to seize business opportunities through the network of suppliers, candidates, consumers, etc. and the way of operation [2]. From the strategic angle, Megretta described business model as the way to create values for consumers and partners and to gain a competitive edge by making good use of related resources [6].

Since 2005, the concept of value has been gradually incorporated to the definition of business model. Value creation, value delivery, value demand and value chain became the buzzwords in the research on business model. One of the most representative definitions was proposed by Chesbrough and Teece, professors at UC Berkeley. Teece considered business model as the logic of how companies deliver value to consumers in seek of income [7]. Chesbrough defined business model as the cooperation and shift between technology development and value creation, including value proposition, market segmentation, value chain definition, income source, income capture, and so on [8]. Yuan Lei argued that business model cannot be explained from a single dimension, and defined it as a "3-4-8" structure [9].

The various studies above are basically grounded on the three dimensions of economy, operation and strategy. In this research, the grounded theory is innovatively implemented in the exploration to the definition of business model and its elements.

\section{GROUNDED THEORY METHODOLOGY}

Proposed by Barney Glaser and Anselm Strauss in 1967, the grounded theory is a systematic methodology in the social sciences involving the construction of theory through methodic gathering and qualitative analysis of data. The theory is widely considered as the most scientific method for qualitative research, and the best one for theory construction in sociology among the five major research methods (the other four are ethnographies, case studies, longitudinal studies and biographies). The birth of the theory marks a major breakthrough in qualitative research.

Over the years, three different schools have formed on the grounded theory: the classical grounded theory proposed by Glaser, the procedural grounded theory proposed by Strauss, and the constructive grounded theory proposed by Charmaz [9]. The classical grounded theory relies on massive data coding and comparison, while the procedural grounded theory labels the types, concepts and categories through open coding, axial coding and selective coding, and then theorizes the relationship among the categories.

The difference between the quantitative research and the grounded theory is explained as follows. The quantitative research is a top-down deductive process. Specifically, the researcher has to raise hypotheses on the relationship among constructs, define the constructs with measurable variables, measure those variables, and validate the relationship against data and documents. By contrast, the constructs and their 
relationship are neither known nor hypothesized in the grounded theory. In order to build up a theory, the researcher needs to observe the information gathered from field survey, extract concepts from mass data, allocate similar concepts into the same category, and find out the relationship between the key categories.

The grounded theory research is a theory building process that transforms data into concepts through constant comparison, reflection and analysis. The core of the research lies in data collection and analysis. This paper emphasizes on the interaction between data collection and analysis. Following data collection, the research will immediately analyse and encode the data, look for new concepts and categories, and compare them with the old ones. These steps are repeated again and again until there is no new concept or category left (the theoretical saturation point).

\section{BUSINESS MODEL DEFINITION AND ELEMENTS BASED ON GROUNDED THEORY}

The fundamental principle of classical grounded theory is to avoid any subjective assumption and ensure that the research questions and final theory are naturally derived from field survey data. Without any theoretical assumption, this paper performs in-depth interviews on business model, looks for the theory hidden behind data, and tries to prevent any interruption of existing theories. During the research, the standard steps of classical grounded theory were adjusted dynamically according to the progress. Here, the procedure was divided into four steps: research question verification, data collection, and data analysis and theory construction [9].

\subsection{Research question verification}

Business model has become a popular word for entrepreneurs and venture capitalists. Almost everyone believes that success is nearly guaranteed with a good business model. So each entrepreneur is fundamentally rethinking the way companies make money, and its own business model. Even though the word business model is wildly used in business and academia, there is still no widely accepted definition and systematic theoretical system of business model, and even no consensus on the fundamental question of what a business model is. With classic grounded theory, this paper tries to find out the essence and core logic of business model by using a large number of materials and interviewing experts of business model.

\subsection{Data collection}

Six business model experts from 6 different enterprises were interviewed one after another. Each interview lasted about 90 minutes, during which the expert answered 6 semiinterview processes was recorded to preserve all key information. Based on the audio recordings, the content of each interview was sorted out and written down in a memo. Following the grounded theory methodology, the six interview memos were sorted, corded and summarized to analyze the definition and elements of business model. Table 1 represents the basic situation of the experts and the questions
Table 1. Basic situation of experts and questions structural questions

\begin{tabular}{|c|c|c|c|c|}
\hline $\begin{array}{l}\text { Inter- } \\
\text { viewee }\end{array}$ & $\begin{array}{l}\text { Employer } \\
\text { Nature }\end{array}$ & Position & $\begin{array}{c}\text { working } \\
\text { (Year) }\end{array}$ & $\begin{array}{c}\text { Manage } \\
\text {-ment } \\
\text { (Year) }\end{array}$ \\
\hline A & $\begin{array}{l}\text { Multinational } \\
\text { Company }\end{array}$ & $\begin{array}{c}\text { Vice } \\
\text { president }\end{array}$ & 33 & 25 \\
\hline B & $\begin{array}{c}\text { Multinational } \\
\text { Company }\end{array}$ & $\begin{array}{l}\text { Business } \\
\text { developmen } \\
\text { t manager }\end{array}$ & 12 & 7 \\
\hline $\mathrm{C}$ & $\begin{array}{c}\text { Multinational } \\
\text { Company }\end{array}$ & $\begin{array}{l}\text { Business } \\
\text { director }\end{array}$ & 21 & 15 \\
\hline $\mathrm{D}$ & $\begin{array}{l}\text { China state } \\
\text { owned } \\
\text { Company }\end{array}$ & $\begin{array}{l}\text { Business } \\
\text { director }\end{array}$ & 18 & 12 \\
\hline $\mathrm{E}$ & $\begin{array}{l}\text { China state } \\
\text { owned } \\
\text { Company }\end{array}$ & $\begin{array}{l}\text { Business } \\
\text { director }\end{array}$ & 20 & 14 \\
\hline F & $\begin{array}{l}\text { Private } \\
\text { Company }\end{array}$ & $\begin{array}{l}\text { Business } \\
\text { manager }\end{array}$ & 12 & 6 \\
\hline
\end{tabular}

\subsection{Date analysis}

Data analysis is a basic and key step to establish a grounded theory. Here, the interview data were examined in three steps: open coding, axial coding and selective coding. In classical grounded theory, coding means the constant comparison between events and concepts, aiming to find more categories, features and concepts of the data.

\subsubsection{Open coding}

Table 2. Part of the results of open coding

\begin{tabular}{|c|c|c|c|}
\hline 8 & Concept & $\begin{array}{c}\text { Category } \\
\text { Characteristic }\end{array}$ & $\begin{array}{c}\text { Category } \\
\text { Dimensions }\end{array}$ \\
\hline A1 & $\begin{array}{l}\text { Customer } \\
\text { needs }\end{array}$ & & \\
\hline A2 & $\begin{array}{c}\text { Customer } \\
\text { Characteristics }\end{array}$ & & \\
\hline A3 & $\begin{array}{l}\text { Customer } \\
\text { Different }\end{array}$ & & \\
\hline A4 & $\begin{array}{l}\text { customer } \\
\text { requirements }\end{array}$ & & \\
\hline A5 & $\begin{array}{c}\text { Consider } \\
\text { customer demand }\end{array}$ & & \\
\hline A6 & $\begin{array}{l}\text { Customer required } \\
\text { value }\end{array}$ & & \\
\hline A7 & $\begin{array}{l}\text { Customer's } \\
\text { customer }\end{array}$ & Target customers' & Product needs, \\
\hline A8 & $\begin{array}{l}\text { Customer needs } \\
\text { affect business } \\
\text { model }\end{array}$ & $\begin{array}{c}\text { goals, needs, } \\
\text { desires, } \\
\text { expectations, etc. }\end{array}$ & $\begin{array}{l}\text { selutions needs, } \\
\text { etc. }\end{array}$ \\
\hline A9 & $\begin{array}{l}\text { Different } \\
\text { customer }\end{array}$ & & \\
\hline A10 & $\begin{array}{c}\text { Customer } \\
\text { segmentation }\end{array}$ & & \\
\hline A11 & $\begin{array}{c}\text { Learn customer } \\
\text { needs }\end{array}$ & & \\
\hline A12 & $\begin{array}{l}\text { Business model } \\
\text { must serve } \\
\text { customer needs }\end{array}$ & & \\
\hline$\ldots$ & $\ldots$ & & \\
\hline A23 & $\begin{array}{c}\text { Customer } \\
\text { purchase power }\end{array}$ & & \\
\hline$\cdots$ & $\begin{array}{c}\ldots \\
\text { (Total } 130 \\
\text { concepts) }\end{array}$ & \multicolumn{2}{|c|}{ (Total 16 categories) } \\
\hline
\end{tabular}

Open coding is conceptualizing on the first level of abstraction. Written data from field notes or transcripts are 
conceptualized line by line. The researcher should not assume any code in advance, but maintain an open attitude. In this research, the first five memos (experts A, B, C, D and E) are read and analysed word by word and sentence by sentence. Then, the key concepts and categories on business model were contrasted. In the end, there were 130 concepts and 16 categories. Due to the lack of space, the coding procedure is omitted here. Table 2 shows part of the results of open coding.

\subsubsection{Axial coding}

Table 3. Categories of axial coding

\begin{tabular}{|c|c|c|c|}
\hline No. & Category & $\begin{array}{c}\text { Category } \\
\text { Characteristics }\end{array}$ & $\begin{array}{c}\text { Occurrence } \\
\text { Frequency }\end{array}$ \\
\hline A1 & $\begin{array}{c}\text { Target } \\
\text { customer needs }\end{array}$ & $\begin{array}{c}\text { Target customers' goals, } \\
\text { needs, desires, } \\
\text { expectations, etc. }\end{array}$ & $16 \%$ \\
\hline $\mathrm{A} 2$ & $\begin{array}{c}\text { Value } \\
\text { propositions }\end{array}$ & $\begin{array}{l}\text { The value provided by } \\
\text { the company to the } \\
\text { customer through its } \\
\text { products and services }\end{array}$ & $14 \%$ \\
\hline A3 & Key activities & $\begin{array}{c}\text { The most important } \\
\text { thing a company has to } \\
\text { do to ensure its business } \\
\text { model is viable }\end{array}$ & $8 \%$ \\
\hline A4 & $\begin{array}{c}\text { Suitable } \\
\text { business model }\end{array}$ & $\begin{array}{l}\text { Choose the suitable } \\
\text { business model } \\
\text { considering the different } \\
\text { market, the product } \\
\text { characteristic and so on }\end{array}$ & $8 \%$ \\
\hline A5 & Target market & $\begin{array}{l}\text { Target market segment } \\
\text { as a business activity }\end{array}$ & $7 \%$ \\
\hline A6 & $\begin{array}{l}\text { Customer } \\
\text { relationships }\end{array}$ & $\begin{array}{c}\text { The relationship between } \\
\text { the company and the } \\
\text { specific customer } \\
\text { segments }\end{array}$ & $6 \%$ \\
\hline A7 & Key resources & $\begin{array}{l}\text { The most important } \\
\text { resources for the } \\
\text { effective operation of } \\
\text { business model }\end{array}$ & $6 \%$ \\
\hline A8 & Competition & $\begin{array}{l}\text { The participation of the } \\
\text { industry and its } \\
\text { competitors, the degree } \\
\text { of competition, it } \\
\text { represents the cost of the } \\
\text { enterprise market and the } \\
\text { level of entry barriers. }\end{array}$ & $6 \%$ \\
\hline A9 & Strategy & $\begin{array}{l}\text { The method used by the } \\
\text { company to achieve } \\
\text { long-term goals }\end{array}$ & $5 \%$ \\
\hline A10 & $\begin{array}{l}\text { Revenue } \\
\text { streams }\end{array}$ & $\begin{array}{l}\text { Income from each } \\
\text { customer group }\end{array}$ & $5 \%$ \\
\hline A11 & $\begin{array}{c}\text { System } \\
\text { description }\end{array}$ & $\begin{array}{l}\text { A entirety consist of } \\
\text { some parts of the } \\
\text { movement, which } \\
\text { interrelated and } \\
\text { interacting with a certain } \\
\text { function. }\end{array}$ & $5 \%$ \\
\hline A12 & Channels & $\begin{array}{l}\text { How companies } \\
\text { communicate and } \\
\text { contact their customer } \\
\text { segmentation and pass } \\
\text { on their value } \\
\text { proposition }\end{array}$ & $4 \%$ \\
\hline A13 & Profit model & $\begin{array}{l}\text { A mechanism or method } \\
\text { of gaining a profit. } \\
\text { All costs arising from }\end{array}$ & $2 \%$ \\
\hline A14 & Cost structure & $\begin{array}{l}\text { the operation of business } \\
\text { model }\end{array}$ & $2 \%$ \\
\hline A15 & $\begin{array}{c}\text { Key } \\
\text { partnerships }\end{array}$ & $\begin{array}{l}\text { Cooperation between } \\
\text { the company and } \\
\text { external partners }\end{array}$ & $2 \%$ \\
\hline A16 & $\begin{array}{l}\text { Operation } \\
\text { model }\end{array}$ & $\begin{array}{l}\text { Mechanism or method } \\
\text { of organic operation of a } \\
\text { company }\end{array}$ & $1 \%$ \\
\hline Total & & & $100 \%$ \\
\hline
\end{tabular}

Despite the abstraction of concepts and categories in open coding, the relationship among categories needs to be clarified. Hence, the axial coding was performed to identify the relationship among concepts, and combine the relevant concepts into categories. In this research, a total of 16 core categories were obtained. All of them, together with their nature and dimension, are displayed in Table 3. These categories are denoted as A1 A16.

\subsubsection{Selective Coding}

Selective coding is targeted at the most important data which linking up the core categories. The core categories can guide subsequent data collection and theoretical sampling. Specifically, a core category was selected from the results of axial coding, and explained via systematic description, verification and supplementation. The coding process was repeated, or the selective coding was redone to let the core category reach the theoretical saturation point . Through the selective coding on the sixth memo (expert F), no new concept or category was discovered, indicating that the core category had reached the theoretical saturation point.

\subsection{Theory construction}

In classical grounded theory, the theory construction is established on theoretical coding. As mentioned by Glaser (1998), theoretical coding is to construct the relationship among concepts and categories, such as causal relationship, progressive relationship, etc.

\subsubsection{Definition of business model}

Based on the classic grounded theory and the previous studies on business model, the author put forward a new definition of business model (Figure 1): business model is a strategy-guided system, composed of marketing model, operation model and profit model, aiming to outperform competitors with better fulfilment of market demand. The definition is further explained below:

First, business model is guided by strategy. That is to say, business model must be geared towards the long-term goals of the company. Second, business model aims to fulfill the market demand better than competitors. For this purpose, both the demand of target consumers and the competition environment should be taken into account. Third, business model must be an organic integration of marketing model, operation model and profit model.

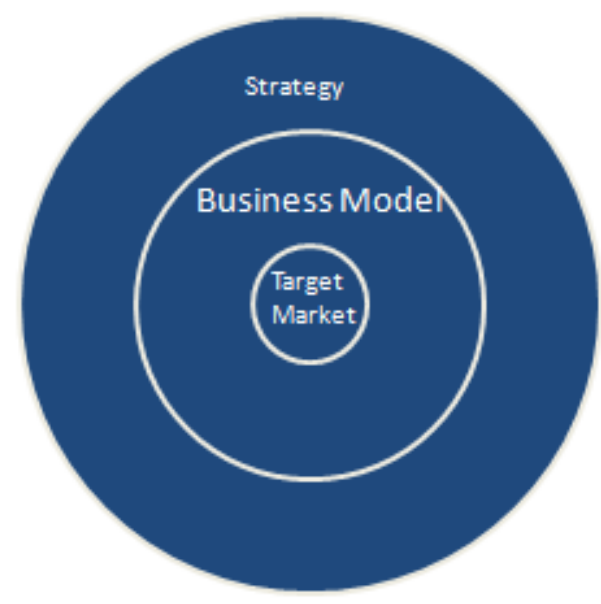

Figure 1. Relationship among business model, strategy and target market of image 


\subsubsection{Elements of business model}

As mentioned above, business model is composed of marketing model, operation mode and profit model. The marketing model depicts how the company delivers its value proposition to target consumers through proper channels. This model involves value proposition, consumer relationships, and channels. The operation model describes how the company guarantees its normal operation through the management of internal resources, maintenance of external cooperation and design of key business activities. This model is composed of key activities, key resources, and external cooperation. The profit model illustrates how the company receives continued profit. It is made up of profit stream and cost structure.

The priority of business model is always the market. In other words, the task of the model is to outshine competitors in fulfilling the demand of target consumers. Therefore, the target market must reside at the centre of the business model map. Meanwhile, business model must serve the strategy and the long-term goal of the company. This means all elements of business model must fall within the strategic framework. Here, a business model target map (BMTM) is developed to give a more intuitive illustration of the relationship among business model elements, strategy and target market (Figure 2). The BMTM was modified from the business model canvas proposed by Alexander Osterwalder and Yves Pigneur.

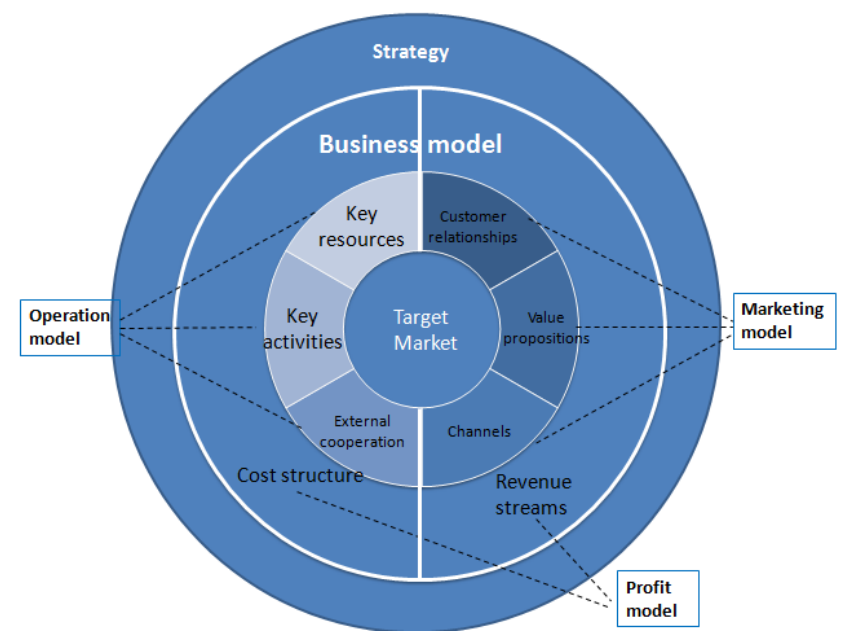

Figure 2. BMTM

\section{THEORETICAL ANALYSIS OF THE BMTM}

As mentioned before, the fundamental principle of classical grounded theory is to avoid any subjective assumption and ensure that the research questions and final theory are naturally derived from field survey data. Nevertheless, the powerful influence of the first impressions often interferes in the theory building. The BMTM completely circumvents first impressions, and refines the theory hidden behind the data. After theory construction, the BMTM was compared with existing theories, with the aim to enhance its theoretical basis. The contrasting theories were introduced as follows.

Kotler and Keller (2006) pointed out the shift from company-lead marketing to market-oriented marketing. Over the years, the focus marketing-related research has moved from production, product, selling, marketing to integration marketing. According to the latest findings on integration marketing, the fulfillment of company goals hinges on the correct identification of market demand, and the creation, delivery and communication of more consumer value than competitors. Besides, marketing should be ubiquitous, allpervasive and unified in vision.

Aiming to reflect the essence of marketing, Kohli and Jaworski (1990) advised to replace the inaccurate expression of "market driving" with "market orientation". The main reasons are: (1) "market driving" is too narrow to reflect the many sectors involved in the concept of marketing other than marketing sector ; (2) "market orientation" avoids the overemphasis on the marketing department, and allows the department to coordinate and share responsibilities with other departments; (3) "market-orientation" expression means market is the focal point, rather than consumers [15]. The effect of market orientation on company performance is a hot topic in strategic management and marketing. Many agree that market orientation has a positive impact on company performance. $\mathrm{Li} \mathrm{Yu}$ (2014) suggested that consumer orientation and competitor orientation are the two dimensions of market orientation, and that the balanced integration of the two orientations can boost company performance [16].

At the end of this research, the preliminary findings were shared with the six experts. All of them were in favor of the BMTM, and agreed that the target market should be the core of business model. Hence, the BMTM highlights the market orientation feature of business model in an increasingly competitive environment.

\section{CONCLUSIONS}

This study explores the definition of business model and its elements. The classical grounded theory was adopted to avoid subject assumptions, extract results directly from survey data and documents, and unearth the preliminary theory from behind the data. Six experts on business model were invited to receive in-depth interviews. During theory building, the preliminary theory was compared with the previous research results on business model. After that, the final version of business model and its elements were put forward. Furthermore, the BMTM was worked out to verify the business model elements and the relationship between the model and strategy and target market.

Most importantly, the author proposed a new definition of business model: business model is a strategy-guided system, composed of marketing model, operation model and profit model, aiming to outperform competitors with better fulfillment of market demand. The definition reflects the relationship between business model and strategy and provides a clear guideline for business model design. On this basis, the author will further study the classification and evaluation of business models, trying to enrich the theoretical system of business model.

\section{REFERENCES}

[1] Yuan L. (2007). Reconstruction of business model theory system. China Industrial Economy 28(6): 70-79.

[2] Morris M, Schindehutte M, Allen J. (2005). The entrepreneur's business model: toward a unified perspective. Journal of Business Research 58(6): 726735. https://doi.org/10.1016/j.jbusres.2003.11.001 
[3] Timmers P. (1998). Business models for electronic markets. Electronic Markets 8(2): 3-8.

[4] Alt R, Zimmermann HD. (2014). Status of business model and electronic market research:An interview with Paul Timmers. Electronic Markets 24(4): 235-241. https://doi.org/10.1007/s12525-014-0177-3

[5] Erez M, Miron-Spector E, Erez M, Naveh E. (2012). To drive creativity add some conformity. Harvard Business Review, March, Harvard Business Review 2012(3): 618.

[6] Pisano P, Pironti M, Rieple A. (2015). Business strategy and innovation. Entrepreneurship Research Journal 43(3): 172-94. https://doi.org/10.1515/erj-2014-0032
[7] Chesbrough H. (2010). Business model innovation: Opportunities and barriers. Long Range Planning 43(2): 354-363. https://doi.org/10.1016/j.lrp.2009.07.010

[8] Heath H, Cowley S. (2004). Developing a grounded theory approach: A comparison of Glaser and Strauss. International Journal of Nursing Studies 41(2): 141-150. https://doi.org/10.1016/S0020-7489(03)00113-5

[9] Li Y, Xie E, Management SO.(2014). The Integration of Customer Orientation and Competitor Orientation and Firm Performance. Journal of Management Science 14(5): 9-16. 